Article

\title{
Intrapreneurial Self-Capital: A Key Resource for Promoting Well-Being in a Shifting Work Landscape
}

\author{
Annamaria Di Fabio ${ }^{1, *}$ and Maureen E. Kenny ${ }^{2}$ \\ 1 Department of Education and Psychology (Psychology Section), University of Florence, Via di San Salvi, \\ 12 Complesso di San Salvi, Padiglione 26, 50135 Firenze, Italy \\ 2 Lynch School of Education, Boston College, Chestnut Hill, MA 02467, USA; maureen.kenny@bc.edu \\ * Correspondence: adifabio@psico.unifi.it; Tel.: +39(0)-55-205-5850; Fax: +39(0)-55-275-6134
}

Received: 28 July 2018; Accepted: 25 August 2018; Published: 27 August 2018

\begin{abstract}
Intrapreneurial Self-Capital (ISC) represents a promising individual resource that might be enhanced through intervention to help individuals cope adaptively with the ongoing changes that characterize the world of work and other life challenges in the 21st century. In order to examine the promise of this construct, the present study analyzed the relationship between ISC and both hedonic and eudaimonic well-being, controlling for the effects of personality traits, which are substantially stable and not amenable to psychological intervention. The Intrapreneurial Self-Capital Scale (ISCS), the Big Five Questionnaire (BFQ), the Positive and Negative Affect Schedule (PANAS), the Satisfaction With Life Scale (SWLS), the Meaning in Life Measure (MLM), and the Flourishing Scale (FS), were administered to 563 Italian university students. Hierarchical regressions analyses showed that ISC explained a percentage of incremental variance beyond that accounted for by personality traits in relation to both hedonic and eudaimonic well-being. These results support the premise that ISC may be a promising resource for fostering both hedonic and eudaimonic well-being.
\end{abstract}

Keywords: Intrapreneurial Self-Capital (ISC), personality traits; hedonic well-being; eudaimonic well-being

\section{Introduction}

The 21st century is characterized by continuous change in the world of work and other life domains [1-6]. Global economic and technological changes have led to increases in unemployment and underemployment in many sectors of the economy and a rise in precarious or short-term contract work and economic inequality [7]. The turmoil and anxiety associated with these changes pose threats to the career development and well-being of individuals who face uncertainty and instability in their work lives [8]. While unemployment, including youth unemployment, has dropped significantly in many regions of the globe in recent years [9]), young people continue to be challenged by unpredictability in the job market and a misalignment between their current skills and those that are sought by employers now and in the future [10].

Faced with an uncertain work future, young people are now responsible for actively managing their careers and balancing their lives. Personal adaptability, intentionality, and life-long learning are increasingly important for maintaining employability $[6,11]$. Rather than focusing on one-time career decision-making, young people need to develop skills for career management $[2,12]$ that support an ongoing process of becoming [2,6]. Indeed, vocational psychologists are recognizing the need for interventions to promote individual capacities for career adaptability $[6,12]$ and self and relational management [13] that can assist individuals in successfully navigating recurring work transitions in the changing and uncertain workplace [14]. Life-design and career- and self-management models 
strive to enable individuals to be proactive in constructing their careers and navigating a difficult work landscape [12,15-19].

In this regard, we suggest that Intrapreneurial Self-Capital (ISC) [2] represents one promising set of psychological resources that might equip individuals to cope adaptively with the uncertainty of the 21st century world of work. ISC could represent an asset for realizing the third of the seventeen UNESCO Sustainable Goals, good health and well-being, and also for realizing the eighth goal, decent work and economic growth. ISC is rooted in the Psychology of Sustainability and Sustainable Development $[20,21]$ by offering personal resources for creatively and constructively coping with ongoing societal change and associated challenges. In the current and future period, ISC may represent a source of positive personal capital that could be accessed to promote flourishing for individuals, and the communities and organizations of which they are a part.

ISC is conceptualized as a set of individual resources that, can be drawn upon for individuals to act as "intrapreneurs" across their careers, coping proactively with frequent work transitions by transforming constraints in one's work life into resources [2]. Di Fabio [2] proposed the notion of ISC by drawing upon the constructs of capital in the career literature [22-24] and intrapreneurship in organizational psychology [25], with the intrapreneur evidencing the personal skills for proactively and successfully meeting changes and challenges within organizations [26]. Di Fabio [2] drew upon contemporary psychological literature and existing research examining the personal characteristics of successful intrapreneurs [27-30] to operationalize the construct of ISC, developing a scale to measure this construct [2] and designing an intervention to build and enhance ISC skills [31].

ISC has been conceptualized as "a higher-order construct containing seven subconstructs: (1) core self-evaluation or positive judgment of oneself in terms of self-esteem, self-efficacy, locus of control, and an absence of pessimism [32]; (2) hardiness or resistance with the three dimensions of commitment, control, and challenge [33]; (3) creative self-efficacy or one's perception of one's ability to solve problems creatively [34]; (4) resilience or the perceived ability to cope with adversity adaptively and to use adaptive strategies to deal with discomfort and adversity [35]; (5) goal mastery or the perceived ability to continuously develop one's own skills [36]; (6) decisiveness or the perceived ability to make timely decisions in any life context [37]; and (7) vigilance or the careful searching for relevant information [38]" [2], pp. 100-102.

A growing body of empirical research suggests that ISC may represent an important set of psychological resources for personal and career development. Given the well-documented relationship between employability, work, and well-being [39,40]. Di Fabio and Kenny [13] proposed and tested through structural equation modeling a framework of Positive Self and Relation Management (PS\&RM). PS\&RM is grounded in the notion that certain individual and relational resources are important for accessing decent work and maintaining overall well-being in today's rapidly changing world. In the model, positive self-management was comprised of intrapreneurial self-capital [2], as well as career adaptability [41], and life project reflexivity [42]. With regard to career development, ISC has shown a positive relationship with scholastic success, career self-efficacy, and employability and a negative relationship with career decision-making difficulties among Italian high school students [2]. With regard to personal outcomes, Di Fabio, Palazzesschi, and Bucci [16] examined the relationship between ISC and well-being among Italian workers. Results not only documented a relationship between ISC and well-being, but also revealed that ISC contributed to both hedonic well-being, defined and assessed by Satisfaction with Life [43], and eudaimonic well-being, defined and assessed by Flourishing [44]. Moreover, ISC was related to well-being beyond the contribution of the Big Five personality traits, which are generally considered substantially stable and not amenable to intervention [45].

The current study seeks to add to the body of research assessing the potential value of ISC as a psychological resource with a specific focus on the well-being of young people [46]. In this regard, we affirm a prevention and positive youth development perspective and the belief that fostering resources to enhance career development and access to decent work should be part of the agenda for 
prevention and positive youth development [14]. With that concern, we seek to replicate and extend the research on ISC and hedonic and eudaimonic well-being among adults in the workforce with university students. Since university students will soon experience the transition from the university to the world of work, the identification and development of individual resources that will facilitate that transition may be pertinent for maintaining well-being and helping them to advance in their work lives, despite the state of economic uncertainty and demands for change.

According to the perspectives of positive psychology [47,48] and primary prevention [11,13,49-54], the enhancement of individual resources can be critical in protecting individuals from potential threats to their well-being and sustaining physical and emotional health over the life course $[11,52]$. In this regard, positive psychology emphasizes the importance of both hedonic [55] and eudaimonic well-being [56]. Hedonic well-being concerns the emotional component of well-being in terms of the prevalence of positive emotions over negative emotions [55], as well as the cognitive evaluation of life satisfaction [43]. Eudaimonic well-being refers to the realization of an optimal level of functioning and self-realization [56], life meaning [57], purposefulness [58], and flourishing [44], defined as social and psychological prosperity in important areas such as relationships, self-esteem, sense of purpose, and optimism. From a prevention perspective $[8,11,13,51-54]$, attention should be given to developing factors that enhance well-being in both the hedonic and eudaimonic domains [2,59].

\section{Aim and Hypotheses}

Given the multifaceted nature of well-being and the potential of ISC to explain well-being beyond the effects of relatively stable personality traits, the aim of the study was to extend existing research on Intrapreneurial Self-Capital (ISC) by examining the relationship of ISC with hedonic well-being (positive affect, negative affect, and life satisfaction) and eudaimonic well-being (meaning in life and flourishing), controlling for the effects of personality traits among university students. This study extends the study of Italian workers [60] by using multiple measures for both hedonic and eudaimonic well-being and using a sample of university students.

The following hypotheses were formulated.

H1. A positive relationship will emerge between Intrapreneurial Self-Capital and positive affect, controlling for the effects of personality traits.

H2. An inverse relationship will emerge between Intrapreneurial Self-Capital and negative affect, controlling for the effects of personality traits.

H3. A positive relationship will emerge between Intrapreneurial Self-Capital and life satisfaction, controlling for the effects of personality traits.

H4. A positive relationship will emerge between Intrapreneurial Self-Capital and meaning in life, controlling for the effects of personality traits.

H5. A positive relationship will emerge between Intrapreneurial Self-Capital and flourishing, controlling for the effects of personality traits.

\section{Material and Methods}

\subsection{Participants}

Five hundred and sixty-three Italian undergraduate students attending a university in the center of Italy participated in the study. Regarding gender, $23.45 \%$ of the participants were men and $76.55 \%$ were women. The participants' ages ranged from 19 to 31 years $(M=23.31, S D=2.51)$. The students were predominantly White Italians from middle-class backgrounds. All students involved in the courses considered in the research were invited to voluntarily participate this study. About $90 \%$ of those enrolled in the courses responded to the survey invitation, with only $10 \%$ declining or failing to fully complete the survey. 


\subsection{Measures}

Intrapreneurial Self-Capital Scale (ISCS). To evaluate intrapreneurial self-capital, the Intrapreneurial Self-Capital Scale (ISC) [2] was used. The ISCS consists of 28 items (e.g., "I am able to deal with most of my problems", "I am able to improve the ideas produced by others", "One of my goals in training is to learn as much as I can") with a response format on a 5-point Likert scale ranging from $1=$ Strongly agree to $5=$ Strongly disagree. A single factor structure was affirmed through second-order confirmatory factor analysis with a Cronbach's alpha coefficient of 0.86 [2]. For the current study, Cronbach's alpha coefficient was 0.84 . The predictive validity of the ISC was supported by a positive relationship between ISC and academic performance in terms of Grade Point Average [2]. Furthermore, the positive association of the ISC with perceived employability [61] and career decision self-efficacy [62] and the inverse relation of ISC with career decision-making difficulties [63] supported concurrent validity of the scale [2].

Big Five Questionnaire (BFQ). The Big Five Questionnaire (BFQ) [64] was used to assess personality traits. The BFQ consists of 132 items with a response format on a 5-point Likert scale, ranging from $1=$ Absolutely false to $5=$ Absolutely true. The questionnaire measures five personality traits, with Cronbach's alpha coefficients of 0.81 for Extraversion, 0.73 for Agreeableness, 0.81 for Conscientiousness, 0.90 for Emotional stability, and 0.75 for Openness. With regard to convergent validity, the five BFQ scales are highly associated with the analogous scales of the NEO Personality Inventory Revised (NEO-PI-R) [45]. Concerning divergent validity, the five BFQ dimensions were not significantly associated with the Wechsler Adult Intelligence Scale (WAIS) [65]. Regarding concurrent validity correlations emerged with the State-Trait Anxiety Inventory, Form x (STAI) [66].

Positive and Negative Affect Schedule (PANAS). To evaluate positive affect (PA) and negative affect (NA) as components of hedonic well-being, the Positive and Negative Affect Schedule (PANAS) [55] in the Italian version by Terracciano, McCrae, and Costa [67] was used. The PANAS is composed of 20 adjectives of which 10 refer to Positive Affect (PA; e.g., enthusiastic, interested, determined) and 10 refer to Negative Affect (NA; e.g., afraid, upset, distressed). The participants are asked to report how they generally feel on average using a Likert scale, ranging from $1=$ Very slightly or not at all to $5=$ Extremely. The Cronbach's alpha coefficients were: 0.72 for Positive Affect and 0.83 for Negative Affect. PANAS has an adequate concurrent validity showing correlations with personality traits (BFQ) [64]: positive between PA and Extraversion and positive between NA and Neuroticism. Furthermore, PANAS presented relationships with the Center for Epidemiological Studies Depression Scale (CES-D) [68]: inverse with PA and positive with NA [68].

Satisfaction With Life Scale (SWLS). The Satisfaction With Life Scale (SWLS) [43] in the Italian version by Di Fabio and Gori [69] was used to evaluate life satisfaction as a second component of hedonic well-being. The scale consists of five items (e.g., "I am satisfied with my life", "The conditions of my life are excellent"), which are rated using a 7-point Likert scale ranging from $1=$ Strongly disagree to 7 = Strongly agree. Cronbach's alpha coefficient was 0.85 . Regarding concurrent validity, the Italian version of the SWLS showed positive correlations with the Rosenberg Self-Esteem Scale [70].

Meaning in Life Measure (MLM). The Italian version [71] of the Meaningful Life Measure [57] was utilized to assess meaning in life as a component of eudaimonic well-being. The questionnaire consists of 23 items, which are rated on a 7-point Likert scale ranging from $1=$ strongly disagree to $7=$ strongly agree. The MLM has five dimensions: Exciting life (e.g., "Life to me seems always exciting"), Accomplished life (e.g., "So far, I am pleased with what I have achieved in life"), Principled life (e.g., "I have a personal value system that makes my life worthwhile"), Purposeful life (e.g., "I have a clear idea of what my future goals and aims are"), and Valued life (e.g., "My life is significant"). The Cronbach's alpha coefficients were 0.85 for Exciting life; 0.87 for Accomplished life; 0.86 for Principled life, 0.85 for Purposeful life; and 0.84 for Valued life, with an alpha value of 0.85 for the total score. Regarding concurrent validity, MLM showed positive correlations with life satisfaction and positive affect and inverse correlations with negative affect [71]. 
Flourishing Scale (FS). The Flourishing Scale (FS) [44] in the Italian version by Di Fabio [72] was used to evaluate flourishing as a second component of eudaimonic well-being. The FS consists of eight items with response options on a 6-point Likert scale ranging from 1 (Strongly disagree) to 7 (Strongly agree). Examples of items include "My social relationships are supportive and rewarding", "I lead a purposeful and meaningful life", and "I am optimistic about my future". The FS showed a unidimensional structure with good reliability: $\alpha=0.88$. The alpha for the current study is 0.92 . A good concurrent validity was showed by the positive correlations of the Italian version of the FS with the Meaningful Life Measure (MLM) [57], the Authenticity Scale (AS) [73], the Satisfaction with Life Scale (SWLS) [43] and the Positive Affect (PA) of the Positive Affect and Negative Affect Scales PANAS [55] and the inverse with the Negative Affect (NA) of the PANAS [55].

\subsection{Procedure}

The questionnaires were administered to the university students in a group setting by trained psychologists according to the requirements of privacy and informed consent of Italian law. Students participated voluntarily in the study and were not compensated. The order of administration was counterbalanced to control for order effects.

\section{Results}

Descriptive statistics, Pearson's $r$ correlations and hierarchical regressions were used. Descriptive statistics and Pearson's r correlations are presented in Table 1.

Table 1. Descriptive statistics and correlations $(n=563)$.

\begin{tabular}{|c|c|c|c|c|c|c|c|c|c|c|c|c|c|}
\hline & 1 & 2 & 3 & 4 & 5 & 6 & 7 & 8 & 9 & 10 & 11 & $M$ & $S D$ \\
\hline 1. BFQ E & - & & & & & & & & & & & 75.24 & 8.88 \\
\hline 2. BFQ A & $0.20 * *$ & - & & & & & & & & & & 79.59 & 8.85 \\
\hline 3. BFQ C & $0.20 * *$ & $0.26^{* *}$ & - & & & & & & & & & 80.51 & 9.81 \\
\hline 5. BFQ O & $0.27^{* *}$ & $0.48^{* *}$ & $0.31 * *$ & $0.12 * *$ & - & & & & & & & 82.18 & 9.93 \\
\hline 6. ISCS & $0.44 * *$ & $0.37 * *$ & $0.22 * *$ & $0.32 * *$ & $0.36^{* *}$ & - & & & & & & 70.76 & 12.39 \\
\hline 7. PA & $0.58 * *$ & $0.24^{* *}$ & $0.30 * *$ & $0.13^{* *}$ & $0.34^{* *}$ & $0.61 * *$ & - & & & & & 34.53 & 6.92 \\
\hline 8. NA & $-0.24 * *$ & $-0.28^{* *}$ & $-0.11 *$ & $-0.40 * *$ & $-0.25^{* *}$ & $-0.50 * *$ & $-0.33 * *$ & - & & & & 24.29 & 8.57 \\
\hline 11. FS & $0.43^{* *}$ & $0.35 * *$ & 0.31 ** & $0.19 * *$ & 0.38 ** & $0.70 * *$ & $0.60 * *$ & $-0.40^{* *}$ & 0.66 ** & $0.79 * *$ & - & 39.18 & 9.65 \\
\hline
\end{tabular}

Table 2 shows the results of five different hierarchical regression models, with positive affect, negative affect, life satisfaction, meaning in life and flourishing serving as the criterion measures in separate analyses and with BFQ entered in step one and ISC in the second step.

Table 2. Hierarchical regression. The contributions of personality traits (first step) and Intrapreneurial Self-Capital (second step) to positive affect (PA), negative affect (NA), life satisfaction (SWLS), meaning in life (MLM) and flourishing (FS) $(n=563)$.

\begin{tabular}{cccccc}
\hline & PA & NA & SWLS & MLM & FS \\
\hline & $\boldsymbol{\beta}$ & $\boldsymbol{\beta}$ & $\boldsymbol{\beta}$ & $\boldsymbol{\beta}$ & $\boldsymbol{\beta}$ \\
\hline Step 1 & & & & & \\
\hline BFQ Extraversion & $0.50^{* * *}$ & $-0.12^{* *}$ & $0.31^{* * *}$ & $0.28^{* * * *}$ & $0.31^{* * * *}$ \\
BFQ Agreeableness & $0.02^{* * *}$ & $-0.12^{* *}$ & $0.22^{* * *}$ & $0.15^{* * *}$ & $0.15^{* * *}$ \\
BFQ Conscientiousness & $0.15^{* * *}$ & -0.04 & 0.07 & $0.20^{* * *}$ & $0.16^{* * *}$ \\
BFQ Emotional stability & $0.03^{* * *}$ & $-0.34^{* * *}$ & $0.13^{* *}$ & $0.12^{* *}$ & $0.10^{*}$ \\
BFQ Openness & $0.16^{* * *}$ & $-0.11^{*}$ & 0.07 & $0.21^{* * *}$ & $0.16^{* * *}$ \\
\hline
\end{tabular}


Table 2. Cont.

\begin{tabular}{cccccc}
\hline & PA & NA & SWLS & MLM & FS \\
\hline Step 2 & $\beta$ & $\beta$ & $\beta$ & $\beta$ & $\beta$ \\
\hline ISCS & & & & & \\
$R^{2}$ step 1 & $0.44^{* * *}$ & $-0.38^{* * *}$ & $0.52^{* * *}$ & $0.54^{* * *}$ & $0.58^{* * *}$ \\
$\Delta R^{2}$ step 2 & $0.40^{* * *}$ & $0.22^{* * *}$ & $0.21^{* * *}$ & $0.37^{* * *}$ & $0.31^{* * *}$ \\
$R^{2}$ total & $0.12^{* * *}$ & $0.09^{* * *}$ & $0.18^{* * *}$ & $0.19^{* * *}$ & $0.23^{* * *}$ \\
\hline & $0.52^{* * *}$ & $0.31^{* * *}$ & $0.39^{* * *}$ & $0.56^{* * *}$ & $0.54^{* * *}$ \\
\hline
\end{tabular}

${ }^{*} p<0.05 .{ }^{* *} p<0.01 .{ }^{* * *} p<0.001$. BFQ = Big Five Questionnaire; ISCS = Intrapreneurial Self-Capital Scale; PANAS PA = PANAS Positive Affects; PANAS NA = PANAS Negative affects; SWLS = Satisfaction with Life Scale; MLM = Meaning in Life Measure; FS = Flourishing Scale.

In the analysis of positive affect as the first indicator of hedonic well-being, personality traits accounted for $40 \%$ of the variance in step one. At the second step, intrapreneurial self-capital added a significant $12 \%$ of incremental variance. The model overall accounted for $52 \%$ of the variance.

For negative affect, personality traits accounted for $22 \%$ of the variance in step one. For step two, intrapreneurial self-capital added a significant $9 \%$ to the incremental variance, with the overall model accounting for $31 \%$ of the variance.

For life satisfaction as the final indicator of hedonic well-being, personality traits accounted for $21 \%$ of the variance in step one, with intrapreneurial self-capital adding a significant $18 \%$ to the incremental variance in the second step. The overall model accounted for $39 \%$ of the variance.

For meaning in life as an index of eudemonic well-being, personality traits accounted for $37 \%$ of the variance in the first step. At the second step, intrapreneurial self-capital added a significant $19 \%$ to the incremental variance, with the overall model accounting for $56 \%$ of the variance.

For flourishing as the second indicator of eudaimonic well-being, personality traits accounted for $31 \%$ of the variance in flourishing. At the second step, intrapreneurial self-capital added a significant $23 \%$ to the variance, with the overall model accounting for $54 \%$ of the variance.

\section{Discussion}

The present study examined among university students the relationship between intrapreneurial self-capital and both hedonic well-being (positive affect, negative affect, and life satisfaction) and eudaimonic well-being (meaning in life and flourishing), controlling for the effects of personality traits.

The study hypotheses were supported revealing positive contributions of ISC to a variety of measures of hedonic and eudaimonic well-being after controlling for personality traits. With regard to hedonic well-being, the first analysis confirmed a positive relationship between intrapreneurial self-capital and positive affect, after controlling for the effect personality traits, documenting a significant association between the set of core intrapreneurial resources and positive emotional activation [55]. The second analysis confirmed an inverse relationship between intrapreneurial self-capital and negative affect [55], with the third analysis also confirming a positive relationship between intrapreneurial self-capital and life satisfaction, after controlling for the effects of personality traits. The findings suggest that higher levels of intrapreneurial resources are associated with higher levels of positive affect and global life satisfaction [43] and lower levels of negative affect.

With regard to eudaimonic well-being, the fourth analysis revealed a positive relationship between intrapreneurial self-capital and meaning in life, controlling for the effects of personality traits, suggesting that having more intrapreneurial resources is associated with the identification and realization of authentic and meaningful goals [57]. For the second dimension of eudaimonic well-being, the findings suggest that higher levels of intrapreneurial resources are associated with a greater presence of social and psychological prosperity or flourishing with regard to relationships, self-esteem, the presence of purpose, and optimism [44]. 
While ISC contributed significantly to all dimensions of well-being, the contribution of ISC for eudaimonic well-being was more robust than the contribution of the affective components of hedonic well-being. That is, intrapreneurial resources appear to contribute to a sense of life meaning and flourishing derived from perceived success in relationships and purposeful self-realization, beyond the mere experience of positive or negative affect. With regard to the construct of hedonic well-being, the contribution of intrapreneurial self-capital was stronger for life satisfaction than for positive and negative affect. Intrapreneurial self-capital may relate more to one's cognitive evaluation of general life satisfaction, than to the elicitation of specific positive or negative affect.

Overall, the findings support the relationships found between ISC and indices of hedonic and eudaimonic well-being that was found in prior research among adults already in the workforce [16], while also providing evidence that ISC contributes to the affective components of hedonic well-being and meaning in life. In both studies, the findings for the contribution of ISC for flourishing were somewhat stronger than for other indices of well-being. Whereas hedonic and eudaimonic well-being are both valuable, flourishing is particularly relevant to models of positive youth development [74] and lifelong positive development [13]. In comparison with a focus on purpose and optimal social and psychological development associated with flourishing, a focus on the pursuit of happiness or pleasure can lead persons to embrace goals and engage in activities that are not ultimately aligned with the realization of their full potential or of benefit to society $[56,75]$.

In conjunction with the contributions of the current study, limitations need to be considered. The results of the present study are not generalizable since the participants were Italian university students from a university in the center of Italy and thus cannot be considered representative of all Italian university students. Future research should therefore expand the study of these variables to participants from different geographical areas in Italy. This study could be also replicated in other countries to examine the cross-cultural relevance of the construct and findings. The findings are also based upon the self-report of participants, so it is not clear whether their self-perceptions of intrapreneurial skills are biased or accurate. Correlational findings do not offer evidence of causality so longitudinal studies are needed to assess change over time and to determine where the presence of ISC and ISC intervention [31] contribute to a variety of long-term outcomes, such as improved coping, enhanced employability, access to decent work, advancement in the workplace and across work settings, and well-being, life satisfaction and personal flourishing. Future research could also examine intrapreneurial self-capital in relation to other aspects of eudaimonic well-being, such as subjective experience of eudaimonia [58], existential fulfillment [76], and authenticity [73].

Despite these limitations and the need for further research to examine the promise of ISC as a construct that is useful for vocational psychology, the results add to the literature showing the contribution of intrapreneurial self-capital to both hedonic and eudaimonic well-being [16,77], as well as to other indices of career development, such as career self-efficacy, career decision-making, and employability, and adaptive well-being, such as hope and acceptance of change [60]. The results of the current study and the broader findings on ISC are aligned with the recognition of overlap in the personal and career domains of human development [39]. Since work meets important psychological needs for identity, meaning, and personal connection [39], work uncertainty and instability threaten both hedonic and eudaimonic well-being [14]. Career development specialists may need to increasingly consider the broad array of psychological resources and career development skills that are needed for individuals to cope and adapt successfully with the challenges of the current and continuously evolving work and social landscapes. In this regard, the resources encompassed in the ISC construct may be important, but not sufficient to prepare for all types of challenges.

The findings with university students also support a prevention and positive youth development perspective in the field of career development [14]. The primary prevention perspective $[8,11,13,51-55,78]$ advocates for the development of individual strengths before the onset of difficulties and across the life course to foster individual well-being. Positive youth development emphasizes the importance of building individual resources and strengths, not only as protective 
factors for coping with challenge, but as resources that allow youth to fully thrive and contribute meaningfully to society [74]. If the results of the present study are replicated and expanded in future research, interventions to develop intrapreneurial self-capital through specific training [2] should be further evaluated to assess their short-term and long-term effectiveness in enhancing intrapreneurial self-capital competencies and assessing their value in preparing young adults to cope with the challenges of the 21st century and sustaining well-being. Interventions that develop different aspects of intrapreneurial self-capital could promote not only the immediate career development and well-being of young adults, but equip them with strengths to flourish in their work and across multiple life domains during a developmental and historical period of tumultuous change and work uncertainty.

While we acknowledge that a variety of social, economic, and political contextual factors beyond the individual pose threats to well-being [54,55], the findings of this study suggest that intrapreneurial self-capital [2] has promise as a set of individual psychological resources that could help individuals to cope with frequent changes and transitions and transform constraints into resources during a period of work change and uncertainty [2]. The constantly changing labor market contributes to a noteworthy loss of decent work, comprising an increase of unemployment, underemployment, and precarious work in different parts of the world [15]. The loss of decent work weakens individual and societal well-being, especially for marginalized people and individuals without highly marketable skills [15]. For this reason, it is important to simultaneously increase individual resources, such as ISC, to equip individuals in facing the challenges of the current world of work, while also adopting a social justice approach to prevention that strives to increase the availability of decent work as a central human right and to reduce the systemic barriers that prevent access to decent work $[15,53,54]$.

The current findings suggest that the set of ISC competencies might be promising for university students in preparing them to cope effectively and sustain well-being in these challenging times. Accordingly, ISC appears to represent a personal resource that may be of value for meeting the seventeen UNESCO Sustainable Goals, in particular goal number three, good health and well-being, and goal number eight, decent work and economic growth. Given evidence supporting the promise of the ISC construct and evidence that it can be increased though specific intervention [2], longitudinal research is needed to assess the causal mechanisms and long-term benefits of the presence of intrapreneurial self-capital and intervention as part of efforts to ensure well-being in a changing society.

Author Contributions: A.D.F. conceptualized the study and the theoretical framework, with M.E.K. helping to select measures. A.D.F. collected the data and, with M.E.K., wrote the methods and results. Then, the authors wrote the discussion together and read and edited the manuscript with several rounds of revisions.

Funding: This research received no external funding.

Conflicts of Interest: The authors declare no conflict of interest.

\section{References}

1. Blustein, D.L. A relational theory of working. J. Voc. Behav. 2011, 79, 1-17. [CrossRef]

2. Di Fabio, A. Intrapreneurial Self-Capital: A new construct for the 21st century. J. Employ. Couns. 2014, 51, 98-111. [CrossRef]

3. Guichard, J. Career guidance, education, and dialogues for a fair and sustainable human development. In Proceedings of the Inaugural Conference of the UNESCO Chair of Lifelong Guidance and Counselling, University of Wroclaw, Wroclaw, Poland, 26-27 November 2013.

4. Peiró, J.M. Stress and coping at work: New research trends and their implications for practice. In The Individual in the Changing Working Life; Näswall, K., Hellgren, J., Sverke, M., Eds.; Cambridge University Press: Cambridge, UK, 2008; pp. 284-310, ISBN 0521879469.

5. Peiró, J.M. Sustainable well-being at work. In Proceedings of the First International Cross-Cultural Conference "Healthier Societies Fostering Healthy Organizations: A Cross-Cultural Perspective", Department of Education and Psychology, University of Florence, Florence, Italy, 26-27 May 2017.

6. Savickas, M.L. Career Counseling; American Psychological Association: Washington, DC, USA, 2011; ISBN 9781433809804. 
7. Standing, G. A Precariat Charter: From Denizens to Citizens. A\&C Black: London, UK, 2014; ISBN 9781472510396.

8. Di Fabio, A.; Kenny, M.E. Promoting well-being: The contribution of emotional intelligence. Front. Psychol. Sect. Org. Psychol. 2016, 7, 1182. [CrossRef] [PubMed]

9. Eurostat. Newsrelease Euroindicaors. 2017. Available online: http://ec.europa.eu/eurostat/ documents / 2995521/8491608/3-30112017-BP-EN.pdf/5206b358-348f-416b-877e-70a75d58f1ef (accessed on 10 January 018).

10. Organization for Economic Cooperation and Development. Securing Livelihoods for All: Foresight for Action; Development Centre Studies; OECD Publishing: Paris, France, 2015. [CrossRef]

11. Di Fabio, A.; Kenny, M.E. The contributions of emotional intelligence and social support for adaptive career progress among Italian youth. J. Career Dev. 2015, 42, 48-49. [CrossRef]

12. Savickas, M.L. Life Designing. What is it? In Proceedings of the Invited Keynote at IAEVG International Conference, Montpellier, France, 24-27 September 2013.

13. Di Fabio, A.; Kenny, E.M. From decent work to decent lives: Positive Self and Relational Management (PS\&RM) in the twenty-first century. Front. Psychol. Sect. Org. Psychol. 2016, 7, 361. [CrossRef]

14. Di Fabio, A.; Kenny, M.E.; Claudius, M. Preventing distress and promoting psychological well-being in uncertain times through career management intervention. In The Cambridge Handbook of International Prevention Science; Israelashvili, M., Romano, J.L., Eds.; Cambridge University Press: Cambridge, UK, 2016; pp. 233-254.

15. Blustein, D.L.; Kenny, M.E.; Di Fabio, A.; Guichard, J. Expanding the impact of the psychology of working: Engaging psychology in the struggle for decent work and human rights. J. Career Assess. 2018. [CrossRef]

16. Di Fabio, A.; Palazzeschi, L.; Bucci, O. In an unpredictable and changing environment: Intrapreneurial Self-Capital as a key resource for life satisfaction and flourishing. Front. Psychol. Sect. Org. Psychol. 2017, 8, 1819. [CrossRef] [PubMed]

17. Di Fabio, A.; Peiró, J.M. Human Capital Sustainability Leadership to Promote Sustainable Development and Healthy Organizations: A New Scale. Sustainability 2018, 10, 2413. [CrossRef]

18. Guichard, J. Self-constructing. J. Voc. Behav. 2009, 75, 251-258. [CrossRef]

19. Savickas, M.L.; Nota, L.; Rossier, J.; Dauwalder, J.P.; Duarte, M.E.; Guichard, J.; Van Vianen, A.E. Life designing: A paradigm for career construction in the 21st century. J. Voc. Behav. 2009, 75, 239-250. [CrossRef]

20. Di Fabio, A. Positive Healthy Organizations: Promoting well-being, meaningfulness, and sustainability in organizations. Front. Psychol. Sect. Org. Psychol. 2017, 8, 1938. [CrossRef] [PubMed]

21. Di Fabio, A. The psychology of sustainability and sustainable development for well-being in organizations. Front. Psychol. Sect. Org. Psychol. 2017, 8, 1534. [CrossRef] [PubMed]

22. Côté, J.E. Sociological perspectives on identity formation: The culture-identity link and identity capital. J. Adolesc. 1996, 19, 419-430. [CrossRef]

23. DeFilippi, R.J.; Arthur, M.B. Boundaryless contexts and careers: A competency-based perspective. In The Boundaryless Career: A New Employment Principle for a New Organizational Era; Arthur, M.B., Rousseau, D.M., Eds.; Oxford University Press: New York, NY, USA, 1996; pp. 116-131, ISBN 0195149580.

24. Luthans, F.; Youssef, C.M.; Avolio, B.J. Psychological Capital: Developing the Human Competitive Edge. Oxford University Press: Oxford, UK, 2007; ISBN 0195187520.

25. Honig, B. Learning strategies and resources for entrepreneurs and intrapreneurs. Entrep. Theory Pract. 2001, 26, 21-35. [CrossRef]

26. Pinchot, G.; Pellman, R. Intrapreneuring in Action: A Handbook for Business Innovation; Berrett-Koehler: San Francisco, CA, USA, 1999; ISBN 1576750612.

27. Cox, C.; Jennings, R. The foundations of success: The development and characteristics of British entrepreneurs and intrapreneurs. Leadersh. Organ. Dev. J. 1995, 16, 4-9. [CrossRef]

28. Davis, K.S. Decision criteria in the evaluation of potential intrapreneurs. J. Eng. Technol. Manag. 1999, 16, 295-327. [CrossRef]

29. Lubkins, L.; Kans, K. Entrepreneurial Strategic Process; Elsevier: London, UK, 2007; ISBN 978-0-7623-1429-4.

30. Ronen, S. Determinants of intrapreneurship among high-tech engineers. In Handbook of Research on High-Technology Entrepreneurs; Malach-Pine, A., Özbilgin, M.F., Eds.; Edward Elgard: Cheltenham, UK, 2010; pp. 233-251.

31. Di Fabio, A.; Van Esbroeck, R. Intrapreneurial Self-Capital: A concept fitting a life-designing intervention. Counsel. Giornale Ital. Ric. Appl. 2016, 9. [CrossRef] 
32. Judge, T.A.; Erez, A.; Bono, J.E.; Thoresen, C.J. The Core Self-Evaluations Scale: Development of a measure. Pers. Psychol. 2003, 56, 303-331. [CrossRef]

33. Maddi, S.R. Issues and interventions in stress mastery. In Personality and Disease; Friedman, S., Ed.; Wiley: New York, NY, USA, 1990; pp. 121-154, ISBN 0471618055.

34. Tierney, P.; Farmer, S.M. Creative self-efficacy: Its potential antecedents and relationship to creative performance. Acad. Manag. J. 2002, 45, 1137-1148. [CrossRef]

35. Tugade, M.M.; Fredrickson, B.L. Resilient individuals use positive emotion to bounce back from negative emotional experiences. J. Pers. Soc. Psychol. 2004, 86, 320-333. [CrossRef] [PubMed]

36. Midgley, C.; Maehr, M.L.; Hruda, L.Z.; Anderman, E.; Anderman, L.; Freeman, K.E.; Urdan, T. Manual for the patterns of adaptive learning scales. Ann Arbor 2000, 1001, 48109-1259.

37. Frost, R.O.; Shows, D.L. The nature and measurement of compulsive indecisiveness. Behav. Res. Ther. 1993, 31, 683-692. [CrossRef]

38. Mann, L.; Burnett, P.; Radford, M.; Ford, S. The Melbourne Decision Making Inventory: An instrument for measuring patterns for coping with decisional conflict. J. Behav. Decis. Mak. 1997, 10, 1-19. [CrossRef]

39. Blustein, D.L. The Psychology of Working: A New Perspective for Counseling, Career Development, and Public Policy; Lawrence Erlbaum Associates: Mahway, NJ, USA, 2006; ISBN 978-0805858792.

40. Blustein, D.L. The role of work in psychological health and well-being: A conceptual, historical, and public policy perspective. Am. Psychol. 2008, 6, 228-240. [CrossRef] [PubMed]

41. Savickas, M.L.; Porfeli, E.J. Career Adapt-Abilities Scale: Construction, reliability, and measurement equivalence across 13 countries. J. Vocat. Behav. 2012, 80, 661-673. [CrossRef]

42. Di Fabio, A.; Maree, J.G.; Kenny, M.E. Development of the Life Project Reflexivity Scale: A new career intervention inventory. J. Career Assess. 2018. [CrossRef]

43. Diener, E.D.; Emmons, R.A.; Larsen, R.J.; Griffin, S. The satisfaction with life scale. J. Pers. Assess. 1985, 49, 71-75. [CrossRef] [PubMed]

44. Diener, E.; Wirtz, D.; Tov, W.; Kim-Prieto, C.; Choi, D.W.; Oishi, S.; Biswas-Diener, R. New well-being measures: Short scales to assess flourishing and positive and negative feelings. Soc. Indic. Res. 2010, 97, 143-156. [CrossRef]

45. Costa, P.T.; McCrae, R.R. NEO PI-R Professional Manual; Psychological Assessment Resources: Odessa, FL, USA, 1992; ISBN 9789997924452.

46. Di Fabio, A.; Kenny, M.E. Academic Relational Civility as a Key Resource for Sustaining Well-Being. Sustainability 2018, 10, 1914. [CrossRef]

47. Seligman, M.E.P. Positive psychology, positive prevention, and positive therapy. In Handbook of Positive Psychology; Snyder, C.R., Lopez, S.J., Eds.; Oxford University Press: Oxford, UK, 2002; pp. 3-9, ISBN 978-0195135336.

48. Seligman, M.E.; Csikszentmihalyi, M. Positive psychology: An introduction. Am. Psychol. 2000, 55, 5-14. [CrossRef] [PubMed]

49. Di Fabio, A.; Kenny, M.E. Promoting emotional intelligence and career decision making among Italian high school students. J. Career Assess. 2011, 19, 21-34. [CrossRef]

50. Di Fabio, A.; Kenny, M.E. The contribution of emotional intelligence to decisional styles among Italian high school students. J. Career Assess. 2012, 20, 404-414. [CrossRef]

51. Di Fabio, A.; Saklofske, D.H. Comparing ability and self-report trait emotional intelligence, fluid intelligence, and personality traits in career decision. Pers. Individ. Differ. 2014, 64, 174-178. [CrossRef]

52. Di Fabio, A.; Saklofske, D.H. Promoting individual resources: The challenge of trait emotional intelligence. Pers. Individ. Differ. 2014, 65, 19-23. [CrossRef]

53. Hage, S.M.; Romano, J.L.; Conyne, R.K.; Kenny, M.; Matthews, C.; Schwartz, J.P.; Waldo, M. Best practice guidelines on prevention practice, research, training, and social advocacy for psychologists. Couns. Psychol. 2007, 35, 493-566. [CrossRef]

54. Kenny, M.E.; Hage, S.M. The next frontier: Prevention as an instrument of social justice. J. Prim. Prev. 2009, 30, 1-10. [CrossRef] [PubMed]

55. Watson, D.; Clark, L.A.; Tellegen, A. Development and validation of brief measures of positive and negative affect: The PANAS scales. J. Pers. Soc. Psychol. 1988, 54, 1063-1070. [CrossRef] [PubMed]

56. Ryan, R.M.; Deci, E.L. To be happy or to be self-fulfilled: A review of research on hedonic and eudaimonic well-being. Annu. Rev. Psychol. 2001, 52, 141-166. [CrossRef] [PubMed] 
57. Morgan, J.; Farsides, T. Measuring meaning in life. J. Happiness Stud. 2009, 10, 197-214. [CrossRef]

58. Waterman, A.S.; Schwartz, S.J.; Zamboanga, B.L.; Ravert, R.D.; Williams, M.K.; Bede Agocha, V.; Kim, S.Y.; Donnellan, M.B. The Questionnaire for Eudaimonic Well-Being: Psychometric properties, demographic comparisons, and evidence of validity. J. Posit. Psychol. 2010, 5, 41-61. [CrossRef]

59. Di Fabio, A.; Palazzeschi, L. Hedonic and eudaimonic well-being: The role of resilience beyond fluid intelligence and personality traits. Front. Psychol. 2015, 6, 1367. [CrossRef] [PubMed]

60. Di Fabio, A.; Palazzeschi, L.; Bucci, O. Intrapreneurial Self-Capital: A resource for healthy people and healthy organizations. Presented at the EAWOP Small Group Meeting Fostering Healthy Organizations: A Cross-Cultural Perspective, University of Florence, Florence, Italy, 19-20 October 2017.

61. Rothwell, A.; Herbert, I.; Rothwell, F. Self-perceived employability: Construction and initial validation of a scale for university students. J. Voc. Behav. 2007, 73, 1-12. [CrossRef]

62. Betz, N.E.; Taylor, K.M. Manual for the Career Decision Making Self-Efficacy Scale (CDM-SES) and CDMSES-Short Form; Ohio State University: Columbus, OH, USA, 2000.

63. Gati, I.; Krausz, M.; Osipow, S.H. A taxonomy of difficulties in career decision making. J. Couns. Psychol. 1996, 43, 510-526. [CrossRef]

64. Caprara, G.V.; Barbaranelli, C.; Borgogni, L. BFQ: Big Five Questionnaire, 2nd ed.; Giunti, O.S.: Firenze, Italy, 1993; ISBN 9788809400672.

65. Wechsler, D. Manual for the Wechsler Adult Intelligence Scale-Revised; The Psychological Corporation: New York, NY, USA, 1981; ISBN B0006YQQPS.

66. Spielberger, C.D.; Gorsuch, R.L.; Lushene, R.E. State-Trait Anxiety Inventory; Consulting Psychology Press: Palo Alto, CA, USA, 1968; ISBN 8809400933.

67. Terracciano, A.; McCrae, R.R.; Costa, P.T., Jr. Factorial and construct validity of the Italian Positive and Negative Affect Schedule (PANAS). Eur. J. Psychol. Assess. 2003, 19, 131-141. [CrossRef] [PubMed]

68. Radloff, L.S. The CES-D scale: A self-report depression scale for research in the general population. Appl. Psychol. Meas. 1977, 1, 385-401. [CrossRef]

69. Di Fabio, A.; Gori, A. Measuring adolescent life satisfaction: Psychometric properties of the Satisfaction with Life Scale in a sample of Italian adolescents and young adults. J. Psychoeduc. Assess. 2016, 34, 501-506. [CrossRef]

70. Rosenberg, M. Society and the Adolescent Self-Image; Princeton University Press: Princeton, NJ, USA, 1965; ISBN 978-0691649443.

71. Di Fabio, A. Meaningful life measure: Primo contributo alla validazione della versione italiana. Couns. G. Ital. Ric. Appl. 2014, 7, 307-315.

72. Di Fabio, A. Fluorishing Scale: Primo contributo alla validazione della versione italiana. Couns. G. Ital. Ric. Appl. 2016, 9. [CrossRef]

73. Wood, A.M.; Linley, P.A.; Maltby, J.; Baliousis, M.; Joseph, S. The authentic personality: A theoretical and empirical conceptualization and the development of the Authenticity Scale. J. Couns. Psychol. 2008, 55, 385-399. [CrossRef]

74. Lerner, R.M.; Almerigi, J.B.; Theokas, C.; Lerner, J.V. Positive youth development: A view of the issues. J. Early Adolesc. 2005, 25, 10-16. [CrossRef]

75. Ryff, C.D.; Singer, B.H. Know thyself and become what you are: A eudaimonic approach to psychological well-being. J. Happiness Stud. 2008, 9, 13-39. [CrossRef]

76. Längle, A.; Orgler, C.; Kundi, M. The Existence Scale: A new approach to assess the ability to find personal meaning in life and to reach existential fulfillment. Eur. Psychother. 2003, 4, 135-146.

77. Di Fabio, A.; Gori, A. Neuroticism and Flourishing in white collars workers: From Self-Esteem to Intrapreneurial Self-Capital for adaptive outcomes. In Neuroticism: Characteristics, Impact on Job Performance and Health Outcomes; Di Fabio, A., Ed.; Nova Science Publishers: New York, NY, USA, 2016; pp. 129-146, ISBN 978-1-63485-323-1.

78. Di Fabio, A.; Kenny, M.E.; Minor, K. School-based research and practice in Italy. In Handbook of Positive Psychology in the Schools, 2nd ed.; Furlong, M.J., Gilman, R., Huebner, E.S., Eds.; Taylor and Francis, Routledge: New York, NY, USA, 2014; pp. 450-464, ISBN 978-0-415-62185-4.

(C) 2018 by the authors. Licensee MDPI, Basel, Switzerland. This article is an open access article distributed under the terms and conditions of the Creative Commons Attribution (CC BY) license (http:/ / creativecommons.org/licenses/by/4.0/). 